\title{
Resistance of a Bacillus subtilis Mutant to a Group of Temperate Bacteriophages
}

\author{
By ANA I. ESTRELA, ${ }^{1}$ HERMÍNIA DE LENCASTRE ${ }^{1,2 *}+$ AND \\ LUIS J. ARCHER ${ }^{1,2}$ \\ ${ }^{1}$ Laboratório de Genética Molecular, Instituto Gulbenkian de Ciência, Oeiras, Portugal \\ ${ }^{2}$ Universidade Nova de Lisboa, Lisbon, Portugal
}

(Received 11 September 1985; revised 2 October 1985)

\begin{abstract}
A mutant of Bacillus subtilis 168 was isolated which resists infection by all the group III temperate bacteriophages except SPR, while allowing full infection by phages of the other groups (I, II and IV). The mutation conferring this phenotype, pha-3, shows $52-54 \%$ PBS1mediated cotransduction with the his $A I$ marker, mapping therefore in the gtaA and gtaB region of the $B$. subtilis chromosome. Nevertheless, it does not affect the infection by phages sensitive to gta mutations.
\end{abstract}

\section{INTRODUCTION}

Very little is known about the adsorption sites of temperate bacteriophages of Bacillus subtilis. These phages were classified by Dean according to their serology, immunity, host range and adsorption site (Dean et al., 1978). The latter criterion, although important, was poorly studied. In $B$. subtilis teichoic acid has been shown to participate in the adsorption of several lytic phages and phage $\phi 105$ (Young, 1967). Resistance to bacteriophages was exhibited by mutants blocked in the glucosylation of wall teichoic acid. Such mutants were shown to fall into three classes, gta $A$, gta $B$ and $g t a C$, according to the gene affected. Hemphill et al. (1980) isolated a $B$. subtilis mutant, resistant to phage SP $\beta c 1$ which was unable to adsorb phages $\phi 3 \mathrm{~T}$ and SP $\beta$ and verified that the resistance marker was cotransducible with the his $A$ gene. F. E. Young (cited in Zahler, 1982) obtained a $\phi 3 T$-resistant mutant which he considered to be a gtaB mutant based on linkage by cotransduction of the mutation with his $A$.

We have isolated a $B$. subtilis adsorption mutant that resists infection by all the group III temperate bacteriophages ( $\phi 3 \mathrm{~T}, \rho 11, \operatorname{SP} \beta, \mathrm{Z}, \mathrm{IG} 1, \mathrm{IG} 3$ and IG4) except SPR, while retaining susceptibility to temperate phages of the other groups (I, II and IV). Based on selective bacteriophage plating efficiencies, this mutant was shown to be different from any of the gta mutants, although it maps in the same region as the gta $A$ and gtaB loci.

\section{METHODS}

The bacterial strains used are listed in Table 1. Lysates of the temperate bacteriophages $\phi 3 T$ (Tucker, 1969), $\rho 11$ (Dean et al., 1976), Z (Hemphill et al., 1980), SP $\beta$ (Warner et al., 1977), SPR (Noyer-Weidner et al., 1983), IG1, IG3 (Fernandes et al., 1983), IG4 (Fernandes et al., 1986), ф105 (Reilly, 1965), SP02 (Okubo \& Romig, 1965) and SP16 (Thorne \& Mele, 1974) were obtained by induction with mitomycin C (Sigma) of the lysogenic strains, as described by Rutberg et al. (1969). Virulent phages $\phi 29, \phi 25, \phi \mathrm{e}$ (Reilly, 1965) and SP01 (Okubo et al., 1964) were amplified on strain CU1050.

Phages were assayed by the two-layer plating procedure (Adams, 1959) with M-agar and M-soft agar (Yehle \& Doi, 1967) supplemented as described by Yasbin et al. (1973). Phage SP16 was assayed on PA-agar and PA-soft agar as used by Thorne (1962). Supplemented M medium (Yasbin et al., 1973) was used for growing bacterial cultures.

† Requests for offprints should be sent to the Oeiras address. 
Table 1. B. subtilis strains

\begin{tabular}{|c|c|c|}
\hline Strain & Genotype & Origin* \\
\hline $\begin{array}{l}\text { CU1050 } \\
\mathrm{IGCg} 112\end{array}$ & $\begin{array}{l}\text { leu } A 8 \text { met } B 5 \text { thr-5 sup-3 attSP } \beta \\
\text { leu } A 8 \text { metB5 thr-5 sup-3 att } S P \beta \text { pha-3 }\end{array}$ & $\begin{array}{l}\text { S. A. Zahler } \\
\text { Spontaneous } \phi 3 \mathrm{~T} \text { resistant } \\
\text { mutant of strain } \\
\text { CU1050 }\end{array}$ \\
\hline BR 151 & lys-3 metB10 trpC2 & F. E. Young \\
\hline IGCg113 & metB10 trpC2 pha-3 & $\begin{array}{l}\text { Congression of } \\
\text { IGCg112 } \rightarrow \text { BR } 151\end{array}$ \\
\hline YB886 & met $B 5 \operatorname{trp} C 2$ xin-1 attSP $\beta$ & R. E. Yasbin \\
\hline IGCg114 & metBS pha-3 & $\begin{array}{l}\text { Congression of } \\
\text { IGCgl12 } \rightarrow \text { YB886 }\end{array}$ \\
\hline RUB807 & lys -3 metB 10 trpC 2 gtaC 20 & F. E. Young \\
\hline RUB808 & lys-3 met B 10 trp C2 gtaA 20 & F. E. Young \\
\hline RUB810 & lys-3 met $B 10$ gtaB 20 & F. E. Young \\
\hline QB800 & hisAl pha-l & R. A. Dedonder \\
\hline $1 \mathrm{GCg} 111$ & lys-3 metB10 pha-2 & M. A. Santos \\
\hline CU1448 & his $A 1$ thr- 5 met $B 5$ att $S P \beta$ & S. A. Zahler \\
\hline QB917 & hisAl thr-5 trpC2 & R. A. Dedonder \\
\hline IGCg301 & hisAl cysB3 trpC2 & H. Paveia \\
\hline
\end{tabular}

* S. A. Zahler, Cornell University, USA; F. E. Young, University of Rochester, USA; R. A. Dedonder, Institut Pasteur, France; M. A. Santos and H. Paveia, Instituto Gulbenkian de Ciência, Portugal.

\section{RESULTS}

B. subtilis mutants resistant to infection by phage $\phi 3 \mathrm{~T}$ were isolated by plating a $\phi 3 \mathrm{~T}$ clear plaque mutant, $\phi 3 \mathrm{~T} c$, on strain CU1050 and picking isolated colonies that survived infection. Colonies which failed to plate $\phi 3 \mathrm{~T} c$, and did not produce phages upon induction with mitomycin $\mathrm{C}$ were selected. One representative $\phi 3 \mathrm{~T}$-resistant mutant was retained for further study. The mutation in this strain was called pha-3 and it was transferred to strains BR151 and YB886 by congression.

The plating of different temperate bacteriophages on the pha-3 mutant IGCg1 12 showed that phages $\phi 3 \mathrm{~T}, \rho 11, \mathrm{SP} \beta, \mathrm{Z}, \mathrm{IG} 1, \mathrm{IG} 3$ and IG4 were unable to infect this mutant, whereas efficiencies of plating for SPR, $\phi 105$, SP02 and SP16 were respectively $1,0.95,0.80$ and 1 . These results are mean values of two experiments and determination of plating efficiencies was as described by Lencastre \& Archer (1980). This mutation was thus shown to confer resistance specifically to the phages of group III with the exception of SPR, while allowing full infection by representatives of the remaining groups of temperate phages.

Adsorption studies showed that strain IGCgl13 (pha-3) is impaired in the adsorption by phage $\phi 3 T$. This phage, as well as the other phages of group III except SPR, was unable to adsorb to strains lacking the $g t a B$ and $g t a C$ gene products, while adsorbing to the gta $A$ mutant. Among the phages tested, only phage SPR adsorbed to pha-3 and gtaB mutants (Table 2).

Besides the three classes of gta mutations which confer resistance to some bacteriophages, two other mutations, pha-1 and pha-2, were isolated which prevent adsorption by phages SP01 (Lepesant-Kejzlarová et al., 1975) and SPP1 (Santos et al., 1983), respectively. We verified that pha-1 and pha-2 mutants (strains QB800 and IGCg111, respectively) were infected with high efficiency by $\phi 3 T c$; plating efficiencies were 0.95 and 0.93 , respectively.

Yasbin et al. (1976) showed that each class of gta mutants can be characterized by a specific pattern of resistance to bacteriophages. In order to compare pha-3 further with the mutations implicated in the glucosylation of cell wall teichoic acid, several phages were tested in the different bacterial mutants (Table 3). As far as the infection pattern of the gta mutants is concerned, our results are in agreement with those of Yasbin et al. (1976). All three gta mutations prevented infection by phages SP01 and $\phi 29$. Phage $\phi 105$ was unable to plate on the gtaA mutant and plating efficiency on the $g t a C$ strain was reduced. Phage $\phi$ e was unable to plate on the gtaC mutant and phages $\phi 25$ and $\phi 3 \mathrm{~T} c$ failed to infect either $g t a B$ or $g t a C$ strains. On the other hand, the newly isolated mutation did not prevent infection by all these phages, including 
Table 2. Percentage adsorption efficiencies of the group III bacteriophages to pha-3 and gta mutants of $B$. subtilis

To $1 \mathrm{ml} \mathrm{M}$-broth was added $1 \mathrm{ml}$ culture $\left(1 \times 10^{8}\right.$ cells $)$ and phage to a m.o.i $\leqslant 0 \cdot 1$. After adsorption for $10 \mathrm{~min}$ at $30^{\circ} \mathrm{C}$ with shaking, samples were centrifuged and supernatants assayed for unadsorbed phages. As a control, host strains were incubated as above in the absence of phage (to assay for liberation of phage SP $\beta$ ). Total phage added was evaluated after incubation as above, without a host strain. Results are mean values of at least two experiments. Efficiencies of adsorption lower than $18 \%$ are considered doubtful or negative because of the experimental error associated with this assay (Wilson \& Takahashi, 1978).

$\begin{array}{lccccc}\text { Phage } & \begin{array}{c}\text { Strain ... BR151 } \\ \left(\text { gta }^{+}\right)\end{array} & \begin{array}{c}\text { IGCg113 } \\ (\text { pha-3) }\end{array} & \begin{array}{c}\text { RUB808 } \\ (\text { gtaA })\end{array} & \begin{array}{c}\text { RUB810 } \\ (\text { gtaB })\end{array} & \begin{array}{c}\text { RUB807 } \\ (\text { gtaC })\end{array} \\ \phi 3 T & 98.7 & 5.0 & 96.2 & 7.1 & 0.6 \\ \rho 11 & 95.2 & 0.0 & 94.3 & 5.9 & 13.1 \\ \text { SP } \beta & 98.1 & 7.9 & 89.2 & 0.02 & 0.0 \\ \text { Z } & 93.0 & 4.2 & 98.2 & 0.1 & 0.0 \\ \text { IG1 } & 98.1 & 0.0 & 97.5 & 14.0 & 7.4 \\ \text { IG3 } & 92.1 & 7.5 & 92.0 & 16.9 & 6.25 \\ \text { IG4 } & 80.0 & 0.0 & 72.3 & 15.1 & 6.1 \\ \text { SPR } & 55.5 & 91.6 & 5.1 & 43.2 & 15.9\end{array}$

Table 3. Plating efficiencies of phages sensitive to gta mutations in B. subtilis

Plating efficiencies are mean values of three different experiments, and are given as the ratio between the number of p.f.u. obtained by plating on the different strains and the number of p.f.u. obtained by plating on strain BR151.

$\begin{array}{lccllc}\begin{array}{c}\text { Strain ... BR151 } \\ \text { Phage }\end{array} & \begin{array}{c}\text { IGCg113 } \\ (\text { gha-3) }\end{array} & \begin{array}{c}\text { RUB808 } \\ (\text { gtaA })\end{array} & \begin{array}{c}\text { RUB810 } \\ (\text { gtaB })\end{array} & \begin{array}{c}\text { RUB807 } \\ (\text { gtaC })\end{array} \\ \text { SP01 } & 1 & 1 \cdot 10 & 0\left(<10^{-8}\right) & 0\left(<10^{-8}\right) & 0\left(<10^{-8}\right) \\ \phi 29 & 1 & 0.90 & 0\left(<10^{-8}\right) & 0\left(<10^{-8}\right) & 0\left(<10^{-8}\right) \\ \phi 25 & 1 & 0.92 & 0.90 & 0\left(<10^{-8}\right) & 0\left(<10^{-8}\right) \\ \phi \mathrm{e} & 1 & 1.20 & 1 \cdot 20 & 0.28 & 0\left(<10^{-8}\right) \\ \phi 105 & 1 & 0.95 & 0\left(<10^{-8}\right) & 0.45 & 0.03 \\ \phi 3 T c & 1 & 0\left(<10^{-8}\right) & 0.91 & 0\left(<10^{-8}\right) & 0\left(<10^{-8}\right)\end{array}$

Table 4. Mapping of the pha-3 mutation relative to hisAl and cysB3 markers by three-factor transduction crosses

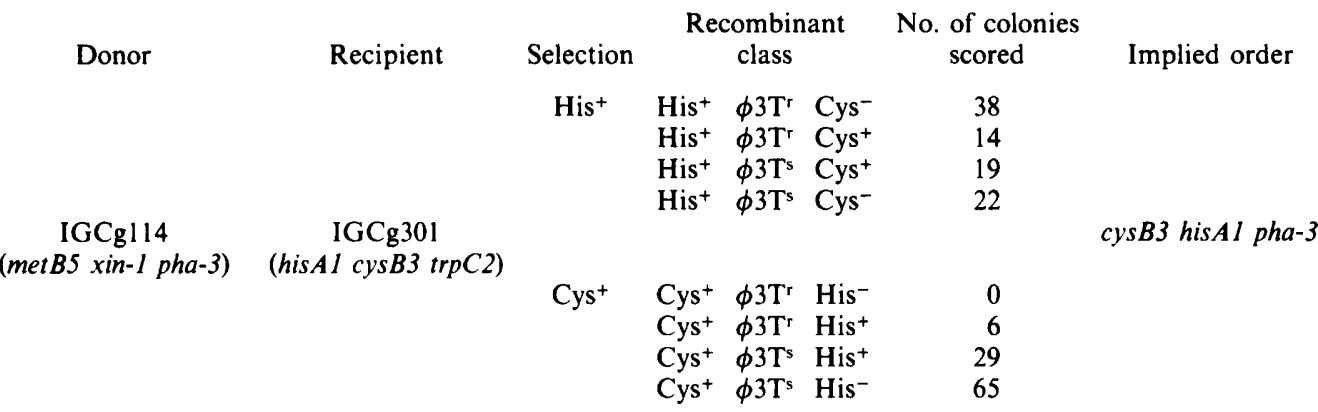

SP01 and $\phi 29$, which have an absolute requirement for glucosylated teichoic acid. The above results show that the pha-3 mutant confers a completely different phage resistance pattern from those conferred by the gta mutants.

The resistance marker was mapped by PBS1-mediated transduction. Transducing lysates were prepared in strain IGCg114 (pha-3) by the method of Karamata \& Gross (1970). Strains CU1448 and QB917 were used as recipients selecting for $\mathrm{His}^{+}$. The pha-3 marker was $52-54 \%$ cotransduced with hisAl; no cotransduction with $t h r-5$ was obtained. Three-factor transduction crosses, using the same lysate and strain IGCg30l as recipient, showed the order of the markers to be cysB3, his Al, pha-3 (Table 4). Since there is a lack of suitable auxotrophic markers in this 
region, mapping by transformation was attempted by direct selection of SP01-resistant transformants of IGCg114, with RUB808 (gtaA) DNA as donor. However, the number of spontaneous SP01-resistant mutants in the transforming cultures was only two- to five-fold lower than the usual number of transformants obtained. Consequently, direct selection for phage resistance upon transformation proved to be unsatisfactory.

\section{DISCUSSION}

We have isolated a $\phi 3$ T-resistant mutant which blocks adsorption of all phages of group III with the sole exception of SPR. The mutation pha-3 is $52-54 \%$ cotransduced with his $A 1$. According to Young et al. (1969) gtaA and gtaB show, respectively, $44 \%$ and $47 \%$ cotransduction with the his $A l$ marker. The pha-3 mutation is thus located in the same region. Nevertheless this mutation confers on the bacterial strains a completely different phage resistance pattern from those associated with all the known gta mutations. Further characterization of the pha-3 mutation is currently in progress.

We wish to thank Dr Margarita Salas for the gift of phage $\phi 29$, Dr Harold Pooley for sending phage $\phi 25$ and Dr Ronald Yasbin for strains RUB807, RUB808 and RUB810.

\section{REFERENCES}

ADAMS, M. H. (1959). Bacteriophages. New York, London \& Sydney: Wiley, Interscience.

Dean, D. H., Orrego, J. C., Hutchinson, K. W. \& Halvorson, H. O. (1976). New temperate bacteriophage for Bacillus subtilis, $\rho 11$. Journal of Virology 20 , 509-519.

DeAN, D. H., ForT, C. L. \& HoCh, J. A. (1978). Characterization of temperate phages of Bacillus subtilis. Current Microbiology 1, 213-217.

Fernandes, R. M., LenCastre, H. DE \& ARCher, L. J. (1983). Two newly isolated temperate phages of Bacillus subtilis. Brotéria-Genética 4(79), 27-33.

Fernandes, R. M., LenCASTRE, H. DE \& ARCHER, L. J. (1986). Three new temperate phages of Bacillus subtilis. Journal of General Microbiology 132 (in the Press).

Hemphill, H. E., Gage, I., Zahler, S. A. \& Korman, R. Z. (1980). Prophage-mediated production of a bacteriocinlike substance by SP $\beta$ lysogens of Bacillus subtilis. Canadian Journal of Microbiology 26, 1328 1333.

Karamata, D. \& Gross, J. D. (1970). Isolation and genetic analysis of temperature-sensitive mutants of Bacillus subtilis defective in DNA synthesis. Molecular and General Genetics 108, 277-287.

LenCASTRE, H. DE \& ARCHER, L. J. (1980). Characterization of bacteriophage SPPI transducing particles. Journal of General Microbiology 117, 347-355.

LePESANT-Kejzlarová, J., Lepesant, J. A., Walle, J., Billault, A. \& Dedonder, R. (1975). Revision of the linkage map of Bacillus subtilis 168: indications of the circularity of the chromosome. Journal of Bacteriology 121, 823-834.

NOYer-Weidner, M., Jentsch, S., PAWlek, B., GüNTHERT, U. \& Trautner, T. A. (1983). Restriction and modification in Bacillus subtilis: DNA methylation potential of the related bacteriophages $\mathrm{Z}, \mathrm{SPR}, \mathrm{SP} \beta, \phi 3 \mathrm{~T}$ and $\rho 11$. Journal of Virology 46, 446-453.

OKubo, S. \& Romig, W. R. (1965). Comparison of ultraviolet sensitivity of Bacillus subtilis bacterio- phage SP02 and its infectious DNA. Journal of Molecular Biology 14, 130-142.

OKubo, S., Strauss, B. \& Stodolsky, M. (1964). The possible role of recombination in the infection of competent Bacillus subtilis by bacteriophage deoxyribonucleic acid. Virology 24, 552-562.

REILLY, B. E. (1965). A study of the bacteriophages of Bacillus subtilis and their infectious nucleic acids. $\mathrm{PhD}$ thesis, Western Reserve University, Cleveland, Ohio, USA.

RutberG, L., Hoch, J. A. \& Spizizen, J. (1969). Mechanism of transfection with deoxyribonucleic acid from the temperate Bacillus bacteriophage $\phi 105$. Journal of Virology 4, 50-57.

Santos, M. A., Lencastre, H. De \& ARcher, L. J. (1983). Bacillus subtilis mutation blocking irreversible binding of bacteriophage SPP1. Journal of General Microbiology 129, 3499-3504.

THORNE, C. B. (1962). Transduction in Bacillus subtilis. Journal of Bacteriology 83, 106-111.

Thorne, C. B. \& Mele, J. (1974). Prophage inter- ference in Bacillus subtilis 168. Microbial Genetics Bulletin 36, 27-29.

TUCKER, R. G. (1969). Acquisition of thymidylate synthetase activity by a thymine-requiring mutant of Bacillus subtilis following infection by the temperate phage $\phi 3$. Journal of General Virology 4, 489-504.

Warner, F. D., Kitos, G. A., Romano, M. P. \& HeMPHILL, E. H. (1977). Characterization of SP $\beta$ : a temperate bacteriophage from Bacillus subtilis 168M. Canadian Journal of Microbiology 23, 45-51.

Wilson, J. J. \& TAKaHASHI, I. (1978). Adsorption of Bacillus subtilis bacteriophage PBS1. Canadian Journal of Microbiology 24, 1-8.

Yasbin, R. E., Wilson, G. A. \& Young, F. E. (1973). Transformation and transfection in lysogenic strains of Bacillus subtilis 168. Journal of Bacteriology 113, 540-548.

Yasbin, R. E., Maino, V. C. \& Young, F. E. (1976). Bacteriophage resistance in Bacillus subtilis 168 , 
W23 and interstrain transformants. Journal of Bacteriology 125, 1120-1126.

YEHLE, C. O. \& DoI, R. H. (1967). Differential expression of bacteriophage genomes in vegetative and sporulating cells of Bacillus subtilis. Journal of Virology 1, 935-947.

YounG, F. E. (1967). Requirement of glucosylated teichoic acid for absorption of phage in Bacillus subtilis 168. Proceedings of the National Academy of Sciences of the United States of America 58, 23772384.
Young, F. E., Smith, C. \& Reilly, B. E. (1969). Chromosomal location of genes regulating resistance to bacteriophage in Bacillus subtilis. Journal of Bacteriology 98, 1087-1097.

ZAHLER, S. A. (1982). Specialized transduction in Bacillus subtilis. In The Molecular Biology of the Bacilli, vol. 1, pp. 269-305. Edited by D. A. Dubnau. New York: Academic Press. 